\title{
Penerapan Realistic Mathematics Education untuk Meningkatkan Aktivitas dan Hasil Belajar Siswa Sekolah Menengah Pertama pada Materi Pokok Fungsi
}

\author{
Dewi Silviana \\ STKIP Bima, Bima, Indonesia, \\ Mikrayanti* \\ STKIP Bima, Bima, Indonesia \\ Rista Salma Jauhari \\ Mahasiswa Prodi Pendidikan Matematika, STKIP Bima, Indonesia \\ M. Furqan \\ Mahasiswa Prodi Pendidikan Matematika, STKIP Bima, Indonesia \\ *Coresponding Author: adehanifatrian@yahoo.com \\ Dikirim: 07-06-2021 ; Direvisi: 08-06-2021 ; Diterima: 08-06-2021
}

\begin{abstract}
Abstrak: Rendahnya hasil belajar siswa terutama pada meteri pokok fungsi. Hal ini disebabkan pembelajaran oleh guru kurang mengaitkan matematika dengan dunia nyata siswa. Akibatnya, siswa kurang mengahayati atau memahami dan rekontruksi konsep-konsep matematika, dan siswa mengalami kesulitan untuk mengaplikasikan matematika dalam kehidupan sehari-hari. Siwa juga kurang aktif dalam proses pembelajaran. Oleh karena itu, agar proses pembelajaran berjalan dengan baik maka diperlukan suatu metode pembelajaran yang melibatkan siswa aktif dalam proses pembelajaran. Metode pembelajaran yang diterapkan disini adalah Realistic Mathematics Education (RME). Penerapan RME memberikan kesempatan kepada siswa untuk menemukan kembali konsep-konsep matematika. Penelitian ini bertujuan untuk Meningkatkan Aktivitas dan Hasil Belajar Siswa Kelas VIII B SMPN 2 Bolo pada Materi Pokok Fungsi Tahun Pelajaran 2019/2020. Jenis penelitian yang digunakan adalah Penelitian Tindakan Kelas (PTK) yang dikalukan dalam dua siklus, dimana siklus I terdiri dari 3 kali pertemuan, 2 kali pertemuan untuk proses pembelajaran dan 1 kali pertemuan untuk evaluasi. Siklus II terdiri dari 2 pertemuan, 1 kali pertemuan untuk pembelajaran dan 1 kali pertemuan untuk evaluasi. Hasil penelitian menunjukkan peningkatan aktivitas dan hasil belajar siswa yang didasari oleh meningkatnya aktivitas dan hasil belajar siswa dari siklus ke siklus. Peningkatan aktivitas belajar siswa pada hasil observasi siklus I dengan kategori sangat aktif, dan siklus II juga aktivitas belajar siswa berkategori sangat aktif. Melalui analisis hasil evaluasi secara keseluruhan dari setiap siklus dapat dilihat adanya peningkatan presentase hasil belajar klasikal dari siklus I 71,29\%, Siklus II 93,35\%. Dengan melihat proses pembelajaran dan hasil evaluasi tersebut, diketahui bahwa Penerapan Realistic Mathematics Education (RME) dapat Meningkatkan Aktivitas dan Hasil Belajar Siswa kelas VIII B SMPN 2 Bolo pada Materi Pokok Fungsi Tahun Pelajaran 2019/2020.
\end{abstract}

Kata Kunci: aktivitas belajar, hasil belajar, fungsi, realistic mathematics education

Abstract: Abstract: The low student learning outcomes, especially in the main function of the material. This is because learning by teachers does not relate mathematics to the real world of students. As a result, students do not appreciate or understand and reconstruct mathematical concepts, and students have difficulty applying mathematics in everyday life. Students are also less active in the learning process. Therefore, in order for the learning process to run well, a learning method that involves active students in the learning process is needed. The learning method applied here is Realistic Mathematics Education (RME). The application of RME provides opportunities for students to rediscover mathematical concepts. This study aims to improve the activities and learning outcomes of Class VIII B students of 
SMPN 2 Bolo on the Main Material Functions for the 2019/2020 Academic Year. The type of research used is Classroom Action Research (CAR) which is carried out in two cycles, where the first cycle consists of 3 meetings, 2 meetings for the learning process and 1 meeting for evaluation. Cycle II consisted of 2 meetings, 1 meeting for learning and 1 meeting for evaluation. The results showed an increase in student activity and learning outcomes based on increased student activity and learning outcomes from cycle to cycle. The increase in student learning activities in the first cycle of observation results in the very active category, and the second cycle in the very active category of student learning activities. Through the analysis of the overall evaluation results from each cycle, it can be seen that there is an increase in the percentage of classical learning outcomes from cycle I $71.29 \%$, Cycle II 93.35\%. By looking at the learning process and the results of the evaluation, it is known that the Application of Realistic Mathematics Education (RME) can Improve Activities and Learning Outcomes of Class VIII B students of SMPN 2 Bolo in the Main Materials of the 2019/2020 Academic Year.

Keywords: learning activities, learning outcomes, functions, realistic mathematics education

\section{PENDAHULUAN}

Berdasarkan undang-undang No 20 Tahun 2003 tentang sistim pendidkan nasional disebutkan bahwa tujuan pendidikan nasional adalah untuk berkembangnya potensi siswa agar menjadi manusia yang beriman dan bertaqwa kepada Tuhan Yang Maha Esa, Berakhlak Mulia, Sehat, Berilmu, Cakap, Kreatif, mandiri dan menjadi warga negara yang demogratis serta bertanggungjawab (Depdiknas: 2003). Dalam mewujudkan tujuan Pendidikan Nasional tersebut, berbagai upaya pendekan dan pembelajaran terus menerus dilakukan. Kaitannya dengan hal ini maka dalam pelaksanaan belajar mengajar, guru dapat memilih dan menentukan metode yang disesuaikan dengan kemampuannya, kekhasan dalam pelajaran, keadaan sarana dan keadaan siswa. Disamping itu seorang guru harus memperhatikan asas-asas didaktik ( dasar-dasar ilmu tentang cara belajar efektif).

Tercapainya tujuan di atas merupakan tolak ukur keberhasilan proses pembelajaran matematika di sekolah. Kenyataan di lapangan bahwa anak-anak pada umumnya banyak yang tidak menyenangi mata pelajaran matematika, bahkan ada pula yang membenci pelajaran matematika (Kusumah dan Suherman, 1993:70). Hal ini berkembang seiring dengan adanya anggapan bahwa matematika dipandang sebagai bidang studi yang kaku, simbolik, dan cenderung jauh dari realita kehidupan sehari-hari. Dari anggapan umum ini kemudian muncul asumsi bahwa untuk mempelajari matematika seseorang harus berfikir serius, abstrak, dan selalu menghafal rumus ( Sudarso, 1998: 65).

Berdasarkan pendapat diatas bahwa matematika merupakan sarana berpikir yang logis, rasional, dan kritis, sehingga ilmu pengetahuan dan tekhnologi atas landasan dan kerangka berpikir matematika dan harus lebih awal diajarkan kepada anak didik.

Mengingat peranan matematika yang begitu penting, maka pengajaran matematika di setiap jenjang pendidikan diharapkan dapat memberikan kontribusi terhadap mutu pendidikan. Berbagai usaha telah dilakukan namun masih menunjukan kekurangan daya serap siswa terhadap pembelajaran yang diberikan setiap jenjang pendidikan. Oleh sebab itu, perlu diupayakan sistem belajar mengajar yang efisien, efektif, dan selektif dengan menggunakan berbagai strategi belajar yang 
tepat sesuai dengan bidang studi dan pokok bahasan yang diajarkan, sehingga standar kompetensi dasar dapat tercapai.

Ada beberapa masalah dalam pembelajaran matematika, pertama yaitu semangat siswa dalam mengikuti proses belajar mengajar terlihat masih rendah. Ini dilihat dalam pembelajaran siswa nampak pasif dan menerima pengetahuan sesuai dengan yang diberikan oleh guru. Hal ini berdampak pada lemahnya siswa dalam memahami konsep-konsep matematika. Hal ini mungkin berkaitan juga dengan permasalahan kedua yaitu kurangnya kemampuan serta kejelian guru dalam menggunakan metode pengajaran. Menurut Djamarah (2003:83) bahwa penggunaan suatu metode mengajar yang monoton cenderung menghasilkan kegiatan belajar mengajar yang membosankan bagi siswa, jalannya pelajaranpun menjadi kaku, siswa kurang gairah belajar, kejenuhan, dan kemalasan menyelimuti kegiatan belajar siswa. Oleh sebab itu, guru matematika dituntut untuk lebih meningkatkan pengetahuannya serta kejelian dalam menggunakan metode dan keterampilan tersebut.

Hal yang mendorong penulis meneliti di kelas VIII B SMPN 2 Bolo karena berdasarkan data, terlihat bahwa hasil belajar matematika pada kelas VIII B SMPN 2 Bolo masih belum memenuhi standar yang diharapkan, yaitu standar sekolah dengan nilai rata kelas $\geq 62$ untuk semua mata pelajaran khususnya mata pelajaran matematika. Berikut adalah Nilai Ulangan Harian siswa Kelas VIII B semester Ganjil pada mata pelajaran matematika SMPN 2 Bolo Tahun Pelajaran 2019/2020.

Tabel 1. Nilai Ulangan harian Mata pelajaran Matematika semester ganjil kelas VIII B SMPN 2 Bolo tahun pelajaran 2019/2020.

\begin{tabular}{|l|l|c|c|}
\hline No & Materi Pokok & Nilai rata-rata & KK \\
\hline 1 & Faktorisasi suku aljabar & 72,53 & $87,76 \%$ \\
\hline 2 & Fungsi & 56,64 & $73,52 \%$ \\
\hline
\end{tabular}

Berdasarkan data di atas terlihat bahwa siswa kelas VIII B SMPN 2 Bolo tahun pelajaran 2019/2020 masih mengalami kesulitan pada materi tertentu, khususnya materi fungsi dengan nilai rata-rata terendah 57,50. Rendahnya prestasi belajar matematika pada siswa yang mengalami masalah secara komperhensif dalam pembelajaran matematika yaitu faktor internal siswa misalnya kesiapan belajar siswa, kemampuan kognitif maupun faktor eksternal seperti kondisi sosial, sarana, dan prasarana serta gaya/pendekatan dalam mengajar.

Setelah melakukan wawancara dengan guru bidang studi matematika SMPN 2 Bolo khusus kelas VIII B, salah satu penyebab rendahnya prestasi belajar siswa khususnya materi fungsi adalah sebagian metode yang digunakan masih bersifat tradisional atau mekanistik. Selama ini proses belajar mengajar didominasi dengan metode ceramah, sehingga dalam waktu yang relatif singkat guru dapat menyelesaikan bahan pelajaran, kenyataan ini diperkuat oleh alasan guru yaitu mengejar target kurikulum. Hal yang demikian merupakan faktor yang menjadikan matematika termasuk pelajaran yang sulit dan akhirnya kurang diminati. Oleh sebab itu, peneliti mencoba dengan pendekatan Realistic Mathematics Education (RME) karena pendekatan ini lebih memfokuskan pada kehidupan nyata siswa dan membentuk lingkungan belajar yang kondusif.

Berdasarkan uraian di atas, maka peneliti bermaksud mengadakan penelitian tindakan kelas yang berjudul "Penerapan Realistic Mathematics Education (RME) 
Untuk Meningkatkan Aktivitas dan hasil Belajar Siswa Kelas VIII B SMPN 2 Bolo pada Materi Pokok fungsi tahun Pelajaran 2019/2020”.

\section{KAJIAN TEORI}

\section{Realistic Mathematics Education (RME)}

Realistic Mathematics Education (RME) merupakan teori belajar mengajar dalam pendidikan matematika. Teori Realistic Mathematics Education (RME) pertama kali diperkenalkan dan dikembangkan di Belanda pada tahun 1970 oleh Institut Freudenthal. Teori ini mengacu pada pendapat freudenthal yang mengatakan bahwa matematika harus dikaitkan dengan realitas dan matematika merupakan aktivitas manusia. Ini berarti matematika harus dekat dengan anak dan relevan dengan kehidupan nyata seharihari. Matematika sebagai aktivitas manusia berarti manusia harus diberikan kesempatan untuk menemukan kembali ide dan konsep matematika dengan bimbingan orang dewasa (Gravemeijer dalam Irzani, 2009:27).

Treffer dalam Bron Web-Site Freundenthal Institut merumuskan dua tipe proses pematematikaan yaitu pematematikaan horisontal dan pematematikaan vertikal. Pematematikaan horisontal adalah peserta didik dengan pengetahuan yang dimilikinya (mathematical tools) dapat mengorganisasikan dan memecahkan masalah nyata dalam kehidupan sehari-hari. Sedangkan pematematikaan vertikal adalah proses reorganisasi dalam sistem matematika itu sendiri, sebagai contoh menemukan cara singkat menemukan hubungan antara konsep-konsep dan strategistrategi, kemudian menerapkan strategi-strategi itu. Singkatnya pematematikaan horisontal berkaitan dengan perubahan dunia nyata mengacu pada simbol-simbol dalam matematika, sedangkan pematematikaan vertikal adalah perubahan dari simbol-simbol ke simbol matematika lainnya (moving within the world of symbol). Meskipun perbedaan dua tipe ini menyolok, tetapi tidak berarti bahwa dua tipe tersebut terpisah sama sekali. Freundenthal menekankan bahwa dua tipe tersebut bernilai sama. (Suharta, 2004:30).

Berdasarkan matematisasi horisontal dan vertikal, pendekatan dalam pendidikan matematika dapat di bedakan menjadi empat jenis yaitu mekanistik, empiristik, strukturalistik, dan realistik. Pendekatan mekanistik merupakan pendekatan tradisional dan didasarkan pada apa yang diketahui dari pengalaman sendiri (diawali dari yang sederhana ke yang lebih kompleks). Dalam pendekatan ini manusia dianggap sebagai mesin. Kedua jenis matematisasi tidak digunakan. Pendekatan emperistik adalah suatu pendekatan dimana konsep-konsep matematika tidak diajarkan, dan diharapkan siswa dapat menemukan melalui matamatisasi horizontal. Pendekatan strukturalistik merupakan pendekatan yang menggunakan sistem formal, misalnya pengajaran penjumlahan cara panjang perlu didahului dengan nilai tempat, sehingga suatu konsep dicapai melalui matematisasi vertikal. Pendekatan realistik adalah suatu pendekatan yang menggunakan masalah realistik sebagai pangkal tolak pembelajaran. Melalui aktivitas matematisasi horizontal dan vertikal diharapkan siswa dapat menemukan dan mengkonstruksi konsep-konsep matematika. (Irzani 2009:27-28).

Pembelajaran matematika yang mengacu pada kotruktivitas sosial dan dikhususkan pada pendidikan matematika. Dalam pandangan Realistic Mathematics Education (RME), pengembangan suatu konsep matematika dimulai oleh siswa secara mandiri berupa kegiatan eksplorasi sehingga matematika memberikan peluang 
kepada siswa untuk berkreasi untuk mengembangkan pemikirannya. Pengembangan konsep berawal dari pengalaman siswa dan siswi menggunakan strateginya masingmasing dalam memperoleh suatu konsep. Guru diharapkan tidak tergesa-gesa menyampaikan pemikirannya kepada siswa tentang suatu hal yang dibahas. Bila suatu materi dirasa sulit, siswa dapat membentuk kelompok kecil, sehingga terjadi negosiasi antar siswa dalam mendiskusikan materi yang sulit tersebut. Jadi peranan guru sebagai fasilitator atau pendamping yang akan meluruskan arah pemikiran siswa, sekiranya jalan pemikiran siswa melenceng jauh dari pokok bahasan yang sedang dipelajari.

Pendidikan matematika dengan istilah realistic, tidak hanya berhubungan dengan dunia nyata saja, tetapi juga menekankan pada masalah nyata yang dapat dibayangkan (to imagine). Kata to imagine sama dengan Zich Realize-Rens dalam bahasa belanda. Jadi penekanannya pada membuat suatu masalah itu menjadi nyata dalam pikiran peserta didik. Dengan demikian konsep-konsep yang abstrak (formal), dapat juga sesuai dan menjadi masalah peserta didik, selama konsep itu berada (dapat diterima oleh) pikiran peserta didik. (Suharta, 2004:32)

Berdasarkan pendapat di atas dapat dikatakan bahwa mata pelajaran matematika itu tidak hanya pada masalah-masalah yang nyata tetapi dapat menjelaskan atau mengubah hal tersebut menjadi masalah yang riil dan nyata dalam kehidupan peserta didik.

\section{Aktivitas dan Hasil Belajar Matematika}

Menurut Djamarah (1992:22) aktivitas belajar adalah suatu perubahan yang terjadi dalam diri individu. Sardiman (2009:96) bahwa yang lebih banyak melakuakan aktivitas di dalam pembentukan diri adalah anak itu sendiri, sedang pendidikan memberikan bimbingan dan merencanakan segala kegiatan yang akan di perbuat oleh anak itu.

Paul B. Diedrich dalam Sardiman (2007:101) membagi kegiatan belajar yang berlandaskan aktivitas dalam 8 kelompok, yaitu:

a. Visual activities, yang termasuk di dalamnya misalnya membaca, memperhatikan demonstrasi, percobaan, pekerjaan orang lain.

b. Oral activities, seperti: menyatakan, merumuskan, bertanya, memberi saran, mengeluarkan pendapat,mengadakan wawancara, diskusi, intrupsi

c. Listening activities, sebagai contoh mendebgarkan: uraian, percakapan, diskusi, musik, pidato.

d. Writing activities, seperti menulis cerita, keterangan, laporan, angket, menyalin

e. Drawing activities, misalnya: menggambar, membuat grafik, peta,diagram.

f. Motor activities, yang termasuk di dalamnyaantara lain: melakukan percobaan, membuat kontruksi, model mereparasi, bermain, berkebun, beternak.

g. Mental activities, sebagai contoh misalnya: menanggapi, mengingat, memecahkan soal,menganalisuis, melihat hubungan, mengambil keputusan.

h. Emotional activities, seperti misalnya: menaruh minat, merasa bosan, gembira, bersemangat, bergairah, berani, tenang, gugup.

Dari uraian di atas dapat disimpulkan bahwa aktivitas belajar adalah suatu bentuk kegiatan yang dilakukan oleh siswa selama kegiatan belajar berlangsung agar siswa memperoleh pengetahuan, pemahaman, keterampilan dan aspek tingkah laku lainya serta mengembangkan keterampilannya agar bermakna. 


\section{METODE PENELITIAN}

\section{Jenis Penelitian}

Jenis penelitian ini adalah Penelitian Tindakan Kelas (PTK). Dalam penelitian ini, peneliti melakukan suatu tindakan, eksperimen yang secara khusus diamati terus menerus, dilihat plus-minusnya, kemudian diadakan pengubahan terkontrol sampai pada upaya maksimal dalam bentuk tindakan yang paling tepat (Arikunto, 2002:2-3).

\section{Pendekatan Penelitian}

Adapun pendekatan penelitian yang digunakan dalam penelitian ini adalah pendekatan penelitian kuantitatif dan kualitatif. Data kualitatif adalah data tentang situasi atau aktifitas belajar mengajar yang diperoleh dengan menggunakan lembar observasi yang telah diisi oleh observer. Sedangkan data kuantitatif adalah hasil belajar siswa.

\section{Tempat dan Waktu Penelitian}

Penelitian ini dilaksanakan di SMPN 2 Bolo pada tahun pelajaran 2019/2020.

\section{Rancangan Penelitian}

Jenis penelitian ini adalah Penelitian Tindakan Kelas (PTK). Proses penelitian ini dilaksanakan dalam dua siklus. Setiap siklus terdiri dari beberapa pertemuan dengan alokasi waktu belajar tiap pertemuan adalah dua jam pelajaran. Dalam tiap siklus dilakukan beberapa langkah penelitian atau rencana tindakan yaitu perencanaan, pelaksanaan tindakan, observasi dan evaluasi, dan reflekasi.

\section{Instrumen Penelitian}

Adapun instrumen yang digunakan dalam penelitian ini adalah sebagai adalah silabus, RPP (Rencana Pelaksanaan Pembelajaran), lembar kerja siswa (LKS), lembar observasi, dan lembar evaluasi.

\section{Teknik Pengumpulan Data}

Sumber data penelitian ini adalah siswa kelas VIII SMPN 2 Bolo, guru dan peneliti. Data prestasi belajar siswa diperoleh dari hasil evaluasi dengan menggunakan tes dalam bentuk essay yang telah disiapkan (Data kuantitatif). Data aktifitas siswa diperoleh dari hasil pengamatan atau observasi (Data kualitatif). Cara pengambilan data dalam penelitian ini, dimana data hasil belajar diperoleh dengan cara memberikan tes evaluasi setiap akhir siklus, sedangkan data tentang situasi proses belajar mengajar didapat dari hasil observasi kegiatan guru dan siswa dalam pelaksanaan proses belajar mengajar.

\section{Teknik Analisis Data}

Ada dua jenis data yang dianalisis, yaitu data hasil observasi dan data hasil tes. Data hasil observasi terdiri dari dua jenis yaitu data aktivitas siswa dan data aktivitas guru.

\section{Data Aktivitas Belajar Siswa}

Data aktivitas siswa dalam proses pembelajaran diperoleh melalui pengamatan langsung dalam setiap pertemuan kelas yang diamati oleh observer yang mengacu pada pedoman observasi yang berisikan 6 indikator, dalam tiap indikator terdiri dari 4 deskriptor.

Menentukan skor yang diperoleh siswa, skor setiap individu tergantung banyaknya perilaku yang dilakukan siswa dari sejumlah indikator yang diamati, 
deskriptor yang diamati sebanyak 3 (tiga) macam deskriptor. Pedoman pemberian skor berdasarkan deskriptor yang muncul dapat dilihat pada Tabel 2.

Tabel 2. Deskriptor aktivitas belajar siswa

\begin{tabular}{|c|c|c|}
\hline No & Deskriptor & Skor \\
\hline 1 & Muncul 3 deskriptor & 4 \\
\hline 2 & Muncul 2 deskriptor & 3 \\
\hline 3 & Muncul 1 deskriptor & 2 \\
\hline
\end{tabular}

Menghitung skor aktivitas belajar siswa dengan rumus sebagai berikut:

$$
\mathrm{M}=\frac{\sum \mathrm{x}_{\mathrm{i}}}{n}
$$

Keterangan:

$\mathrm{M} \quad$ = skor rata-rata aktivitas belajar siswa

$\Sigma \mathrm{x}_{\mathrm{i}} \quad=$ jumlah skor aktivitas seluruh siswa

$\mathrm{N} \quad=$ banyak siswa

Kemudian hasil dari skor aktivitas siswa tersebut dibandingkan dengan hasil dari MI dan SDI yang dirumuskan sebagai berikut:

$$
\begin{aligned}
& \text { MI }=\frac{1}{2} \times(\text { Skortertinggi }+ \text { Skorterendah }) \\
& \text { SDI }=\frac{1}{6} \times(\text { Skor tertinggi }- \text { Skor terendah })
\end{aligned}
$$

Keterangan:

$$
\begin{aligned}
& \text { MI = Mean Ideal } \\
& \text { SDI = Standar Deviasi Ideal }
\end{aligned}
$$

Untuk menentukan standar keaktifan siswa dapat dicari dengan rumus pada Tabel 3. Berdasarkan pedoman observasi aktivitas siswa diketahui skor tertinggi adalah 24 dan skor terendah adalah 12, maka nilai $\mathrm{MI}=19$ dan SDI = 2,3 sehingga interval nilai data aktivitas siswa dapat dilihat pada tabel berikut ini.

Tabel 3. Pedoman Kategori Aktivitas Belajar Siswa Untuk Meningkatkan Hasil Belajar Siswa Kelas VIII B dengan penerapan Realistic Mathematics Education (RME) tahun pelajaran 2019/2020.

\begin{tabular}{|l|c|c|}
\hline \multicolumn{1}{|c|}{ Rumus } & Interval Nilai & Kategori \\
\hline $\mathrm{MI}+2 \mathrm{SDI} \leq \mathrm{M} \leq \mathrm{MI}+3 \mathrm{SDI}$ & $17,4 \leq \mathrm{M} \leq 20,01$ & Sangat Aktif \\
\hline $\mathrm{MI}+1 \mathrm{SDI} \leq \mathrm{M}<\mathrm{MI}+2$ SDI & $14,7 \leq \mathrm{M}<17,4$ & Aktif \\
\hline $\mathrm{MI}-1 \mathrm{SDI} \leq \mathrm{M}<\mathrm{MI}+1$ SDI & $10,7 \leq \mathrm{M}<14,7$ & Cukup Aktif \\
\hline $\mathrm{MI}-2 \mathrm{SDI} \leq \mathrm{M}<\mathrm{MI}-1$ SDI & $6,7 \leq \mathrm{M}<10,7$ & Kurang Aktif \\
\hline $\mathrm{MI}-3 \mathrm{SDI} \leq \mathrm{M}<\mathrm{MI}-2$ SDI & $4,0 \leq \mathrm{M}<6,7$ & $\begin{array}{c}\text { Sangat Kurang } \\
\text { Aktif }\end{array}$ \\
\hline
\end{tabular}

(Nurkencana, 1990 dalam Ramadhan 2009)

\section{Data Aktivitas Guru}

Data aktivitas guru dalam proses pembelajaran diperoleh melalui pengamatan langsung dalam setiap pertemuan di kelas oleh observer yang mengacu pada pedoman observasi yang berisikan deskriptor-deskriptor dalam indikator perilaku 
guru. Deskriptor yang ada dalam pedoman observasi berjumlah 3 deskriptor dalam setiap indikator perilaku guru.

Berdasarkan lembar observasi aktivitas guru diketahui skor tertinggi adalah 35 dan skor terendah adalah 14 karena data aktivitas guru dihitung dengan menggunakan rumus yang sama dengan data aktivitas siswa, maka nilai $\mathrm{MI}=24,5$ dan nilai SDI $=3,5$, sehingga diperoleh interval nilai data aktivitas guru dapat dilihat pada Tabel 4.

Tabel 4. Pedoman Kategori Aktivitas Guru Untuk Meningkatkan Hasil Belajar Siswa Kelas VIII B dengan penerapan Realistic Mathematics Education (RME) tahun pelajaran 2019/2020.

\begin{tabular}{|c|c|c|}
\hline \multicolumn{1}{|c|}{ Rumus } & Interval Nilai & Kategori \\
\hline $\mathrm{MI}+2 \mathrm{SDI} \leq \mathrm{M} \leq \mathrm{MI}+3 \mathrm{SDI}$ & $26 \leq \mathrm{M} \leq 30$ & Baik Sekali \\
\hline $\mathrm{MI}+1 \mathrm{SDI} \leq \mathrm{M}<\mathrm{MI}+2 \mathrm{SDI}$ & $22 \leq \mathrm{M}<26$ & Baik \\
\hline $\mathrm{MI}-1 \mathrm{SDI} \leq \mathrm{M}<\mathrm{MI}+1 \mathrm{SDI}$ & $14 \leq \mathrm{M}<22$ & Cukup \\
\hline $\mathrm{MI}-2 \mathrm{SDI} \leq \mathrm{M}<\mathrm{MI}-1 \mathrm{SDI}$ & $10 \leq \mathrm{M}<14$ & Kurang \\
\hline $\mathrm{MI}-3 \mathrm{SDI} \leq \mathrm{M}<\mathrm{MI}-2 \mathrm{SDI}$ & $6 \leq \mathrm{M}<10$ & Kurang Sekali \\
\hline
\end{tabular}

\section{Data Tes Hasil Belajar}

Setelah memperoleh data tes hasil belajar, maka data tersebut dianalisa dengan mencari ketuntasan belajar dan daya serap, kemudian dianalisa secara kuantitatif.

\section{Ketuntasan Individu}

Setiap individu dalam proses belajar mengajar dikatakan tuntas apabila memperoleh nilai lebih besar atau sama dengan nilai 62 Nilai ketuntasan minimal sebesar 62 dipilih karena sesuai dengan kemampuan individu, hal ini sesuai dengan standar ketuntasan belajar minimal yang diterapkan oleh sekolah tempat peneliti melakukan penelitian.

\section{Ketuntasan Klasikal}

Data tes hasil belajar proses pembelajaran dianalisis dengan menggunakan analisis ketuntasan hasil belajar secara klasikal minimal 85\% dari jumlah siswa yang memperoleh nilai 62 ke atas. Dengan rumus ketuntasan belajar klasikal adalah:

$$
\begin{aligned}
& \mathrm{KK}=\frac{X}{Z} \times 100 \% \\
& \text { Dimana: } \\
& \mathrm{KK}=\text { Ketuntasan Klasikal } \\
& \mathrm{X}=\text { Jumlah siswa yang memperoleh nilai } 62 \text { ke atas } \\
& \mathrm{Z}=\text { Jumlah seluruh siswa (Nurkencana:1999) }
\end{aligned}
$$

Ketuntasan belajar klasikal tercapai jika $\geq 85 \%$ siswa memperoleh skor minimal 62 yang akan terlihat pada hasil evaluasi tiap - tiap siklus.

\section{HASIL PENELITIAN}

Penelitian ini dilaksanakan dalam 2 (dua) Siklus dengan objek penelitian adalah Siswa Kelas VIII B SMPN 2 Bolo Semester Ganjil, hasil penelitian tiap-tiap siklus adalah sebagai berikut:

\section{Siklus I}

Pelaksanaan pengajaran dilaksanakan sebanyak 3 kali pertemuan, dua kali pertemuan untuk pembelajaran dan satu pertemuan untuk evaluasi, untuk mengamati 
proses pembelajaran guru didampingi oleh 1 orang observer yang akan mengamati aktivitas guru selama proses pembelajaran berlangsung, sementara lembar observasi aktivitas siswa digunakan untuk menilai aktivitas siswa dan yang menjadi pengamatnya adalah guru itu sendiri.

Berdasarkan hasil observasi siklus I selama dua kali pertemuan skor rata-rata siswa dapat dilihat pada tabel berikut:

Tabel 5. Data Hasil Observasi Aktivitas Siswa Siklus I

\begin{tabular}{|c|c|c|c|c|}
\hline Siklus I & $\begin{array}{c}\text { Banyak } \\
\text { Siswa }\end{array}$ & $\begin{array}{l}\text { Skor } \\
\text { Total }\end{array}$ & Rata-Rata & Kategori \\
\hline Pertemuan I & 38 & 615 & 16,18 & Aktif \\
\hline Pertemuan II & 38 & 709 & 18,66 & Sangat akif \\
\hline \multicolumn{3}{|c|}{ Total Skor Rata-Rata } & 34,84 & \multirow{2}{*}{ Sangat Aktif } \\
\hline \multicolumn{3}{|c|}{ Skor Rata-Rata Siklus I } & 17,42 & \\
\hline
\end{tabular}

Berdasarkan data di atas maka dapat diketahui bahwa dengan Realistic Mathematics Education (RME) secara individu dapat meningkatkan aktivitas belajar siswa selama proses pembelajaran pada siklus I.

Berdasarkan hasil observasi pada siklus I dari 2 kali pertemuan, skor rata-rata aktivitas guru dapat dilihat pada tabel berikut:

Tabel 6. Data Hasil Observasi Aktivitas Guru Siklus I

\begin{tabular}{|c|c|c|}
\hline Siklus I & Skor total rata-rata & kategori \\
\hline Pertemuan I & 17 & Cukup baik \\
\hline Pertemuan II & 19 & Cukup baik \\
\hline Total skor rata-rata & 36 & Cukup baik \\
\hline Skor rata-rata siklus I & 18 & \\
\hline
\end{tabular}

Berdasarkan hasil observasi dari para pengamat mengenai aktivitas guru pada siklus I, guru sudah cukup mampu menciptakan pembelajaran yang baik dengan penerapan Realistic Mathematics Education (RME) secara individu serta memotivasi siswa untuk belajar, namun disisi lain masih terdapat kekurangan-kekurangan yang mesti diperbaiki untuk siklus selanjutnya.

\section{Tahap Evaluasi}

Berdasarkan hasil evaluasi yang telah dilaksanakan diperoleh data seperti pada tabel berikut ini.

Tabel 7. Data Hasil Evaluasi Siklus I

\begin{tabular}{|c|l|c|}
\hline No. & \multicolumn{1}{|c|}{ Hasil Evaluasi } & Keterangan \\
\hline 1. & Jumlah seluruh siswa & 38 Siswa \\
\hline 2. & Jumlah siswa yang ikut tes & 29 Siswa \\
\hline 3. & Jumlah siswa yang tidak ikut tes & 9 Siswa \\
\hline 4. & Jumlah Soal tes & 5 Nomor \\
\hline 5. & Jumlah Siswa yang memperoleh nilai $\geq 62$ & 20 Siswa \\
\hline 6. & Jumlah siswa yang memperoleh nilai $<62$ & 9 Siswa \\
\hline 7. & Rata-rata nilai siswa & 51,76 \\
\hline 8. & Persentase Ketuntasan & $71,29 \%$ \\
\hline
\end{tabular}


Hasil evaluasi siklus I menunjukan bahwa nilai rata-rata siswa adalah 51,76 dan persentase siswa yang mendapat nilai $\geq 62$ atau telah mencapai ketuntasan belajar adalah sebesar 71,29\%. Dari data hasil evaluasi belajar ini dapat disimpulkan bahwa ketuntasan klasikalnya belum tercapai karena hanya mencapai 71,29\%. saja, sementara ketuntasan klasikal itu dapat tercapai apabila persentase ketuntasan belajar siswa memperoleh $\geq 85 \%$. Pada siklus I ini masih ada 9 siswa yang masih belum tuntas secara maksimal, sehingga perlu adanya pendekatan-pendekatan khusus kepada siswa yang bersangkutan.

Pada tahap refleksi peneliti bersama observer (pengamat) mengkaji pelaksanaan dan hasil yang diperoleh dalam proses pembelajaran pada siklus I. Sebagai acuan dalam siklus ini adalah hasil observasi dan evaluasi. Hasil evaluasi ini digunakan sebagai dasar untuk memperbaiki serta menyempurnakan perencanaan dan pelaksanaan pengajaran pada siklus berikutnya.

Setelah diadakan pengamatan selama aktivitas pembelajaran di dalam kelas, selanjutnya diadakan refleksi atas segala aktivitas yang telah dilakukan, hasil refleksi adalah sebagai berikut:

1) Dalam menyampaikan materi pelajaran guru masih mendominasi, menyebabkan siswa tidak tergerak untuk terlibat secara aktif.

2) Sebagian siswa masih terpengaruh dengan suasana kelas, apabila ada yang membuat keributan merekapun ikut-ikutan.

3) Sebagian siswa masih suka mengganggu siswa lain ketika mengerjakan tugas

4) Guru dalam menjelaskan materi pelajaran kurang dipahami oleh beberapa siswa, terutama siswa yang lamban dalam menyerap materi, sehingga ada siswa yang diam saja sewaktu diberi pertanyaan oleh guru.

5) Setelah diadakan evaluasi pada siklus I diperoleh nilai rata-rata sebesar 51,76. Untuk siswa yang mendapatkan nilai $<62$ sebanyak 9 orang sedangkan yang mendapatkan nilai $\geq 62$ yaitu sebanyak 20 orang dengan persentase sebesar $71,29 \%$.

6) Secara garis besar, pelaksanaan siklus I berlangsung cukup baik, walaupun belum mencapai ketuntasan klasikal. Untuk itu kegiatan pembelajaran pada siklus I perlu diulang agar kemampuan siswa dalam mengerjakan soal tentang Materi Fungsi dapat ditingkatkan lagi dengan melakukan perbaikan-perbaikan.

Dari beberapa kekurangan diatas, guru berusaha untuk memperbaiki pola ajar yang terlebih dahulu disepakati dengan para observer tentang apa-apa saja yang perlu dipersiapkan maupun dilaksanakan pada siklus selanjutnya agar mencapai hasil yang benar-benar diharapkan. Langkah-langkah perbaikan yang dilaksanakan oleh guru untuk perbaikan pada siklus II adalah:

1) Guru bertindak sebagai fasilitator dan meminimalisir perannya yang dapat membuat siswa terlihat pasif

2) Guru menciptakan suasana kelas yang kondusif, sehingga tidak ada lagi siswa yang mengganggu temannya selama proses pembelajaran.

3) Memberi pemahaman kepada siswa untuk tidak mengganggu siswa lain dalam mengerjakan tugas karena akan mengganggu konsentrasi dan mempengaruhi nilai siswa yang bersangkutan.

4) Ketika menyampaikan materi pelajaran guru, guru sedikit memberikan penekanan pada materi-materi yang dianggap sulit oleh siswa terutama kepada siswa yang lamban dalam menerima materi. 


\section{Siklus II}

Pada siklus II pelaksanaan kegiatan belajar hanya dilakukan satu kali pertemuan. Siklus II diadakan perbaikan-perbaikan mengenai hal-hal yang masih kurang yang dilaksanakan oleh peneliti berdasarkan hasil refleksi pada siklus I. Pada siklus II diperoleh data hasil observasi aktivitas siswa dan aktivitas guru selama proses pembelajaran dengan penerapan Realistic Mathematics Education (RME) secara individu pada siklus II memperoleh kategori sangat aktif, karena seluruh siswa mampu melaksanakan sebagian besar deskriptor-deskriptor yang ada pada lembar observasi. Hasil observasi siklus II dari satu kali pertemuan dan skor rata-rata aktivitas siswa dapat dilihat pada tabel berikut:

Tabel 8. Data Hasil Observasi Aktivitas Belajar Siswa Siklus II

\begin{tabular}{|c|c|c|c|c|}
\hline Siklus II & $\begin{array}{c}\text { Banyak } \\
\text { Siswa }\end{array}$ & $\begin{array}{c}\text { Skor } \\
\text { Total }\end{array}$ & Rata-Rata & Kategori \\
\hline Pertemuan I & 38 & 777 & 20,44 & Sangat aktif \\
\hline & & & & \\
\hline \multicolumn{2}{|c|}{ Total Skor Rata-Rata } & 20,44 & \multirow{2}{*}{ Sangat aktif } \\
\hline \multicolumn{2}{|c|}{ Skor Rata-Rata Siklus II } & 20,44 & \\
\hline
\end{tabular}

\section{Hasil Observasi Aktivitas Guru Siklus II}

Berdasarkan hasil observasi pada siklus II dari satu kali pertemuan, skor ratarata aktivitas guru dapat dilihat pada tabel berikut:

Tabel 9. Data Hasil Observasi Aktivitas Guru Siklus II

\begin{tabular}{|c|c|c|}
\hline Siklus I & Skor total rata-rata & Kategori \\
\hline Pertemuan I & 22 & Baik \\
\hline Total skor rata-rata & 22 & Baik \\
\hline Skor rata-rata siklus I & 22 & \\
\hline
\end{tabular}

\section{Tahap Evaluasi}

Berdasarkan hasil evaluasi yang telah dilaksanakan diperoleh data seperti pada tabel berikut ini.

Tabel 10. Data Hasil Evaluasi Siklus II

\begin{tabular}{|c|l|c|}
\hline No. & \multicolumn{1}{|c|}{ Hasil Evaluasi } & Keterangan \\
\hline 1. & Jumlah seluruh siswa & 38 Siswa \\
\hline 2. & Jumlah siswa yang ikut tes & 35 Siswa \\
\hline 3. & Jumlah siswa yang tidak ikut tes & 3 Siswa \\
\hline 2. & Jumlah soal tes & 5 Nomor \\
\hline 3. & Jumlah siswa yang memperoleh nilai $\geq 62$ & 32 Siswa \\
\hline 4. & Jumlah siswa yang memperoleh nilai $\leq 62$ & 3 Siswa \\
\hline 5. & Rata-rata nilai siswa & 71,45 \\
\hline 6. & Persentase ketuntasan & $93,35 \%$ \\
\hline
\end{tabular}

Berdasarkan tabel di atas dapat diketahui bahwa masih ada 2 siswa yang belum tuntas, dari hasil observasi memang siswa ini kurang cepat dalam menyerap materi, meskipun sudah dilakukan perbaikan-perbaikan untuk mengatasinya. Hasil evaluasi siklus II menunjukan bahwa nilai rata-rata siswa adalah 71,45 dan persentase siswa 
yang mendapat nilai $\geq 62$ adalah 93,35\%. Dari data hasil evaluasi belajar ini dapat disimpulkan bahwa ketuntasan klasikalnya sudah tercapai dengan sangat baik, ini menunjukan bahwa dengan perbaikan-perbaikan yang dilakukan pada siklus II dapat menghasilkan peningkatan yang sangat signifikan terhadap hasil belajar siswa, sehingga penelitian berakhir pada siklus II.

\section{Refleksi}

Hasil refleksi atas pelaksanaan siklus II, dihasilkan hal-hal sebagai berikut:

1) Suasana kelas tertib, terkendali dan kondusif. Dengan demikian proses belajar mengajar dapat berjalan dengan lancar.

2) Siswa bertambah terampil dalam menyelesaikan tugas secara individu.

3) Seluruh siswa aktif dalam melaksanakan kerja tanpa membedakan yang pandai dan yang kurang pandai.

4) Siswa sudah memanfaatkan waktu dengan baik untuk mengerjakan tugas.

5) Keberanian siswa semakin tumbuh. Sebagian besar siswa mengacungkan jarinya terlebih dahulu untuk menjawab petanyaan.

6) Siswa yang menjadi penyaji hasil tugas tampak sungguh-sungguh dan percaya diri, sehingga teman yang lain menanggapinya dengan penuh perhatian.

Siklus II dipandang sudah cukup baik, karena 93,35\% siswa memperoleh nilai lebih dari 62 sehingga sudah mencapai ketuntasan klasikal. Berdasarkan temuan hasil refleksi dalam siklus II ini secara keseluruhan pembelajaran Matematika dengan materi pokok Fungsi berlangsung dengan baik. Hasil belajar siswa kelas VIII B SMPN 2 Bolo pada materi pokok Fungsi dapat ditingkatkan. Hal ini tampak dari analisis hasil evaluasi yang telah dilakukan setelah pelaksanaan siklus II.

\section{PEMBAHASAN}

Berdasarkan hasil penelitian, observasi proses belajar mengajar pada setiap siklus memberikan gambaran tentang pelaksaan proses belajar mengajar di kelas VIII B menunjukkan bahwa tingkat keaktifan siswa dan antusiasme siswa cukup baik dalam merespon materi pembelajaran. Secara terperinci aktivitas dan hasil belajar akan dibahas menyeluruh berdasarkan hasil evaluasi dan refleksi pada setiap siklusnya.

Pada siklus I hasil observasi aktivitas siswa untuk dua kali pertemuan, siswa sudah mencapai kotegori cukup aktif dengan rata-rata skor aktivitas sebesar 18 . Peningkatn aktivitas siswa secara khusus dapat dilihat pada beberapa siswa antara lain Ahmad Hairuman Haqiqi dengan skor total aktivitas 14 dan pada pertemuan kedua skor aktivitasnya mencapai 18, Azmi Maulidya pertemuan pertama skor aktivitasnya 18 sedangkan pada pertemuan kedua mengalami peningkatan pada skor 21, hal ini menunjukkan bahwa terjadi peningkatan aktivitas pada siklus I. Hasil observasi aktivitas guru selama dua kali pertemuan dengan kotogori cukup baik serta skor rata-rata aktivitas sebesar 18, seperti yang tampak pada lembar observasi aktivitas guru dapat dilihat bahwa untuk setiap idikator dari 6 deskriptor masih ada beberapa indikator yang belum muncul pada pertemuan pertama misalnya pada indikator 3 untuk deskriptor 1sehingga perolehan skor 3 hal ini disebabkan karena guru belum mampu memotovasi siswa pada pertemuan pertama sedangkan pada pertemuan kedua guru sudah mampu memberikan motivasi kepada siswa pada saat proses belajar berlangsung. Dari hasil evaluasi siklus I menunjukkan bahwa persentase siswa yang tuntas belajar sebanyak 71,29\%, dengan nilai rata-rata 51,76 
Walaupun belum mencapai ketuntasan klasikal dan nilai rata-rata siswa lebih rendah dari tahun sebelumnya yaitu 57,50. Belum tercapainya ketuntasan klasikal dan rendahnya rata-rata individu ini disebabkan oleh 9 siswa tidak mengikuti evaluasi siklus I dengan keterangan 6 orang alpa dan 3 orang siswa sakit. Berdasarkan hasil evaluasi prestasi belajar siswa dengan berpatokan pada lembar jawaban menunjukkan bahwa butir soal yang tidak dapat diselesaikan dengan sempurna adalah butir soal nomor 5. Secara umum rendahnya ketuntasan klasikal dan rata-rata nilai siswa disebabkan karena adanya faktor-faktor yang mempengaruhi hasil belajar baik faktor internal maupun faktor eksternal (Ahmadi,2005), yang bisa saja berasal dari guru maupun siswa.

Hasil refleksi siklus I mengisyaratkan perbaikan pada pelaksanaan pengajaran pada siklus selanjutnya antara lain bahwa peran guru dalam mengorganisasikan aktivitas-aktivitas belajar siswa perlu dioptimalkan dan yang tidak kalah pentingnya guru harus bisa menciptakan suasana belajar yang menyenangkan supaya siswa tidak mengalami kejenuhan dalam mengikuti pelajaran.

Pada siklus II guru berupaya meningkatkan keterlibatan siswa dan membangkitka respon siswa dalam proses pembelajaran. Dari hasil analisis data diperoleh bahwa hasil observasi aktivitas siswa mampu mencapai katogori aktif, dengan skor aktivitas paling rendah adalah 18 yang mampu dicapai oleh Muhammad Zulhan dan skor paling tinggi adalah 22 dicapai oleh Andi Ristiyaningsih, Angga Putradi, Azmi Maulidya. Hasil observasi aktivitas guru dengan kategori baik sesuai dengan data pada lembar observasi aktivitas guru menunjukkan bahwa rata-rata indikator muncul untuk setiap deskriptornya dan hanya pada deskriptor 3 dan 1 untuk indikator 3 dan 4 . Hasil belajar siswa mencapai ketuntasan klasikal yaitu dengan persentase 93,35\% dengan rata-rata 71,45. Pad siklus II siswa masih mengalami kesulitan untuk menyelesaikan butir soal nomor 5 tetapi dengan persentasi yang lebih rendah dan dapat disimpulkan bahwa siklus II ini terjadi peningkatan hasil belajar siswa, peningkatan prestasi siswa tersebut dapat dilihat pada aspek daya ingat materi prasarat, pemahaman konsep dan prinsip, kemampuan berfikir dalam menjawab persoalan secara individu dan kualitas diskusi. Hal tersebut menandakan meningkatnya keaktifan dan respon siswa, sehingga dapat membangkitkan minat dan pemahaman dalam belajar matematika.

Berdasarkan analisis hasil penelitian di atas maka peneliti beserta observer merefleksi bahwa penerapan Realistic Mathematics Education (RME) sangat cocok untuk meningkatkan hasil belajar siswa. Hasil evaluasi sudah mencapai standar ketuntasan klasikal bahkan lebih yaitu 93,35\%, hal ini menunjukan bahwa sebagian besar siswa mampu mencapai standar kriteria ketuntasan minimal (KKM), begitu pula dengan hasil observasi aktivitas guru dan siswa selalu terjadi peningkatan tiap pertemuannya dan pada akhir pertemuan pada siklus II seluruh siswa dapat melaksanakan sebagian besar deskriptor yang ada. Hal ini menunjukan bahwa terjadi peningkatan hasil belajar siswa dibandingkan dengan tahun sebelumnya. Namun disisi lain untuk kedepan guru harus tetap membuat gebrakan-gebrakan baru dalam penerapan Realistic Mathematics Education (RME) agar siswa tidak bosan dengan model pembelajaran yang diterapkan. Dengan perolehan hasil di atas dapat disimpulkan bahwa melalui penerapan Realistic Mathematics Education (RME) dapat meningkatkan hasil belajar siswa dengan materi Pokok Fungsi kelas VIII B SMPN 2 Bolo Tahun Pelajaran 2019/2020. 


\section{KESIMPULAN}

Mengacu pada tujuan penelitian sebagaimana di rumuskan pada bab I berdasarkan hasil penelitian yang telah dilakukan dapat disimpulkan bahwa, pembelajaran matematika dengan Penerapan Realistic Mathematics Education ( $R M E$ ) dapat Meningkatkan Aktivitas dan Hasil Belajar Siswa pada Kelas VIII B SMPN 2 Bolo dapat dilihat pada siklus I persentase ketuntasan klasikal sebesar 71,29 $\%$ dan materi Pokok Fungsi Tahun Pelajaran 2011/2012. Hal ini skor rata-rata aktivitas belajar siswa sebesar 17,42 dengan kategori sangat aktif. Pada siklus II persentase ketuntasan klasikal sebesar $93,35 \%$ dan skor rata-rata aktivitas belajar siswa 20,44 dengan kategori sangat aktif. Hasil penelitian menunjukan adanya peningkatan baik dari segi hasil belajar maupun aktivitas belajar siswa.

Berdasarkan hasil penelitian yang telah dilakukan, beberapa saran diantaranya adalah bagi siswa, bagi guru, dan bagi penelitian yang akan datang. Bagi siswa diharapkan lebih meningkatkan kreatifitas dalam membuat/mengajukan soal. Kemudian bagi guru perlu dilakukan penerapan pembelajaran matematika dengan penerapan Realistic Mathematics Education (RME) pada materi pokok Fungsi. Serta bagi Peneliti lainnya diharapkan dapat mencoba penerapan Realistic Mathematics Education (RME) pada materi pokok lainnya.

\section{DAFTAR PUSTAKA}

Arikunto, S, 2002. Prosedur Penelitian Suatu Pendekatan Praktik. Jakarta: Rineka Cipta.

Depdiknas RI, 2003. Undang-undang No 20tahun 2003 tentang sistem Pendidikan Nasional, depertemen pendidikan nasional Republik Indonesia. Jakarta.

Djamarah..S.B, 2003. Pisikologi Belajar. Jakarta: Rinnneka Cipta.

Fauzan, Ahmad, 2001. Pendidikan Matematika Realistik Suatu Tantangan Dan Harapan. Disajikan Dalam Seminar PMR di Universitas Sanata Dharma. Yogyakarta.

Furchan, Arief, 2007. Pengantar Penelitian Dalam Pendidikan. Yogyakarta: Pustaka Belajar.

Hamalik, Oemar, 2008. Proses Belajar Mengajar. Jakarta: Bumi Aksara.

Heruman, 2008. Model Pembelajaran Metematika Di Sekolah Dasar. Bandung: PT Remaja Rosdakarya.

Husain Tampones, 2005, Metematika SMP/MTs kelsa VIII. Jakarta: Yudistira

Irzani, 2009. Strategi Belajar Mengajar Matemtika. Yogyakarta: Media Grafindo Press.

Mulyasa, 2003. Kurikulum Berbasis Kompetensi. Bandung: PT Remaja Rosdakarya.

Nurkencana, 2000. Evaluasi Pendidikan. Surabaya: Usaha Nasional.

Parayitno, S, 2003. RME Suatu Alternatif Pembelajaran Matematika Dalam Menyongsong Kurikulum Berbasis Kompetensi. Mataram: Universitas Mataram.

@ 2021 JagoMipa (https://bimaberilmu.com/jurnal/index.php/jagomipa) 
Poerwadarminta. 1983 Kamus Umum Bahasa Indonesia. Jakarta: Balai Pustaka.

Sagala, Syaiful, 2008. Konsep Dan Makna Pembelajaran. Bandung: Alfabeta.

Sardiman. 2008. Interaksi Dan Motivasi Belajar Mengajar. Jakarta: PT raja grapindo Persada.

Simanjuntak, Lisnawati, 1993. Metode Pengajaran Matematika. Jakarta: Rineka Cipta.

Slameto. 2003. Belajar dan faktor-faktor yang mempengaruhinya. Jakarta:

Subana, dkk, 2005. Statistik Pendidikan. Bandung: Pustaka Setia.

Suharta, Putu, IG, 2004. Matematika Realistik: Apa Dan Bagaimana? Depdiknas:

Zaenurie. Realistic Mathematics Education (RME), http// Zaenurie. Wordpress.com/2007/04/13 Pembelajaran Matematika Realistik (RME). 